\title{
Accounting Information and Stock Prices of Quoted Manufacturing Firms: Multi-variant Panel Data Evidence from Nigeria
}

\author{
Okoro Innocent \\ Department of Accounting \\ Faculty of Management Sciences \\ University of Port Harcourt, Rivers State, Nigeria \\ E-mail: innocentokoro35@yahoo.com \\ E.A.L. Ibanichuka \\ Department of Accounting \\ Faculty of Management Sciences \\ University of Port Harcourt, Rivers State, Nigeria \\ L.C. Micah \\ Department of Accounting \\ Faculty of Management Sciences \\ University of Port Harcourt, Rivers State, Nigeria
}

\begin{abstract}
This study the relationship between accounting information and the stock prices of quoted firms in Nigeria. The general objective was to examine if accounting information have any effect on market value of quoted firms. Cross sectional data was sourced from financial statement of 23 manufacturing firm from 2008-2017. Stock price of the firms was modeled as a function of assets turnover rate, book value per share and debt equity ratio. Ordinary least square method of cointgration, unit root and granger causality test was used to determine the extent to which human resource cost affect quality of financial report. After cross examination of the validity of the pooled effect, fixed effect and the random effect, the study accepts the fixed effect model. The study found that the independent variables explained 78 percent variation on the market value of the quoted firms. The beta coefficient of the variables indicates debt equity ratio and assets turnover rate have positive effect on the stock prices of the quoted firms while book value per share have negative effect on the stock prices of the manufacturing firms. From the regression summary, the study concludes that there is significant relationship between accounting information and prices of the quoted firms. The study recommends that management of the manufacturing firms should formulate policies that will increase book value per share and internal and external factors that affect negatively the book value per share of the firms should be discouraged.
\end{abstract}

Keywords: Accounting Information, Market Value, Quoted Manufacturing Firms, Panel Data, Nigeria.

\section{Introduction}

Prior to the deregulation of stock market in Nigeria, stock prices of newly issued and existing stocks were regulated by the regulatory agent of the market, the Nigerian Securities and Exchange Commission, without reference to internal factors such as financial information that can affect stock prices of listed firms. Stock prices in the Nigerian stock Exchange moves up and down in response to news and information expected about the particular stock in the market. The news and information cause buyers and sellers of common stocks to take buying and selling decisions which generate market activities that affect market value (Aflbi and Dada, 20I4). Stock price constitute the value of a firm (Pandey, 2005).

The effect of stock volatility arising from the role of accounting information disclosure in mitigating uncertainty, accounting disclosures may reduce the magnitude of the impact of news about a firm's performance, which would reduce stock price volatility (Lang and Lundholm 1993; Bushee and Noe 2000). Retrospectively, the market microstructure theory also suggest that by increasing the amount of public information, disclosure is likely to reduce information asymmetries in the market that result in pronounced price changes in response to changes in demand for the stock (Diamond and Verrecchia I99I). 
Disclosure reduces heterogeneity of beliefs about the true value of the firm. It may thus reduce both the volume traded and the volatility of the stock price.

An increase in disclosure implies that more information is released, which in and of itself might move the price and increase volatility (Ross 1989). An increase in the disclosure of information relies on sophisticated investors to interpret and put the disclosed information into context. Indeed specific disclosure requirements could provide the markets with more data that might be misconstrued by analysts. More disclosure might thus inject more market volatility (Institute of International Finance 2003; Shleifer and Vishny 1997).

In Nigeria, Section 296 of Companies and Allied Matter Act 1990 (as amended) mandates all public limited companies to make public the financial status of the firm within a specific accounting period. The role of management as agent to the shareholders gives it obligation to be accountable to the owners. Management is responsible for the preparation of financial statement based on the accounting records of the organization which reflects the nature and operations of the entity and expected to be in conformity with Generally Accepted Accounting Principle (GAAP).

The need for financial reporting and disclosure arises from information asymmetry and conflict of interest between managers and shareholders (Healy and Palepa, 2006).According to International Accounting Standard Board (IASB), (2008), high quality financial reporting is critical to investors and other stakeholders in making investment, credit and similar decision. The need for adequate fair, reliable, relevant, timely and unbiased financial information is irrefutable in a free enterprise economy.

Information is related to various theories such as stakeholder theory (Choi, 1973), agency theory (Piot, 2005, and Stulz 2005), legitimacy theory (Deegan, 2002 and Tsang, 1998) and political economy theory (Choi, I973). Information dissemination is an important and effective tool of coordinating all those groups to bring them together. Beuselinck (2005) clearly evidences quoting other relevant theories linked to economic functions that financial reporting quality is prime to wellfunctioning of the economy. The development of accounting theory originated in the United States as a result of the corporate scandals in the early 1900s and later was influenced by the establishment of professional accounting bodies in the United State and the United Kingdom that published documents relating to accounting principles and standards for financial statements (Schroeder, et al., 20II). Mandatory disclosure of reported financial statements is an important source of information with significant economic implications for investors, creditors, firms and other users. The usefulness of financial information for investor decision-making process has been the focus of many researchers since the 1960s.

Accounting information, such as that conveyed in publicly disclosed accounting reports, is also critical to the analysis of temporal liquidity positions of equity markets. Disclosure of accounting information arguably reduces information asymmetries amongst investors (Amihud and Mendelson, 1986). As argued by Black (2000) and Ball (200I) timely financial accounting disclosure system that is a prerequisite to the very existence of efficient stock markets in which stock prices to a considerable extent reflects all public information and incorporates private information as well as communicate the information set to managers, current and potential investors. Accounting information plays a very important role in our society for making efficient business decisions.

However according to the international accounting standard board an accounting standard board general purpose financial reports are not designed to show the value of a reporting entity; but they provide information to help existing and potential investors, lenders, and other creditors to estimate the value of the reporting entity (FASB, 2010). Investors and other users of financial reports rely on models derived from finance theories to make investment decisions. There are numerous theories relating to the decision-making process of equity investors, this includes the capital asset pricing model and fundamental analysis models, among others.

The asymmetric information theory financial markets are especially characterized by informational differences between buyers and sellers. Private information and modeling it to financial economics created another perspective on financial information as determinants of market value most especially in the developing financial markets like Nigeria whose degree of market imperfection is close to unitary. These theories proclaim that insiders, such as management, are assumed to possess superior, private information about the firm's characteristics concerning income stream as well as investment opportunities. Therefore this study examined the effect of accounting information on the market value of quoted manufacturing firms in Nigeria.

\section{Literature Review}

\section{I Accounting Information}

Accounting information can be seen as the outcome of accounting systems that measure and routinely disclose audited, quantitative data concerning the financial position and performance of an enterprise. Audited balance sheets, income statements, and cash-flow statements, along with supporting disclosures, form the foundation of the financial accounting reports to investors and indeed a wide range of accounting information users. Financial statements have the ability to perform a number of functions. They basically provide financial aid to managers in decision making, measurement or evaluation of a firm's performance, and 
also to portray a firm's value. Thus, for disclosed financial information to be useful, it must be relevant and faithfully represent what it purports to represent. The usefulness of financial information is enhanced if it is comparable, verifiable, timely and understandable (Conceptual Framework, 2010).

Financial information supplies a key quantitative representation of Individual Corporation that supports a wide range of contractual relationships. According to the American Institute of Certified Public Accountants (AICPA. 2005), financial statements must properly reflect the organization's financial and economic reality, so that the users are not induced to take decisions on misleading information. Financial information also enhances the information environment of the reporting entity and those associated with it. The quality of financial disclosure can impact on firms' cash flows directly, in addition to influencing the cost of capital at which the cash flows are discounted. Financial information, such as that conveyed in publicly disclosed accounting reports, is also critical to the analysis of temporal liquidity positions of equity markets.

Financial information is information which describes an account for a utility. It processes financial transactions to provide external reporting to outside parties such as to stockholders, investors, creditors, and government agencies etc. For financial reporting to be effective, accounting information should be completed as relevant and reliable (Hendricks, I976). The primary purpose of the financial statements is to provide information about a company in order to make better decisions particularly the investors (Germon and Meek, 200I).

\subsection{The Concept of Stock Price}

Stock price is the cost of purchasing a security on an exchange. It is affected by a number of factors including volatility in the market, current economic conditions, and popularity of the company. According to Ronen and Yaari (2008), the invention of double entry book keeping in the I4th century led to company's valuation which is based upon ratios such as price per unit of earnings (from income statement), price per unit of net worth (from balance sheet) and price per unit of cash flow (cash flow statement). The next advance was to price individual price shares rather than the whole company. A price per dividend was the next advancement. Analysts find it appropriate to use discounted cash flow that is based on time value of money to estimate the intrinsic value of share rather than price per dividend of share prices.

Stock price is based on supply and demand. It is used to refer to as a company's market capitalization value. It is calculated by multiplying the number of shares issued by the price of the company's share. A company's share price is determined by daily trading between buyers and sellers on the relevant stock exchange. Market prices are easy to determine for assets as the constituent values, such as stock and futures prices, are readily available. A valuation would have to be prepared using different methods (Ngerebo-a, 2007).

Stock price is the value of an asset/security as determined by the forces of demand for and supply of the assets. It is the perceived or observed value of an asset on the market. It is also known as current value. It is in fact the mutually accepted worth (cost or price depending on the individual) of the asset after negotiation. Most assets that have market values have their values determined by specialized markets such as the stock exchange. The acceptance of any asset depends on the perception of the potential investor after comparing the Stock price to the intrinsic value. An asset is undervalued or under-price or favorably priced if the market value of the asset is less than the intrinsic value. If the intrinsic value of the asset is less the market value, then the asset is overvalued, over-priced or favorably priced. Where the latter occurs, the investor would ordinarily be acquiring an asset at more expensive value than he would ordinarily have paid. An investor would acquire an overpriced asset if he expects the asset to record a bullish price movement such that if the anticipated price movement crystallizes, the investor can make capital gain.

\subsection{Asset Turnover Ratio}

Assets turnover defined as the efficiency ratio which demonstrates the efficiency utilization of company's assets in generating company's sales. By using formula given by Malik and Ali (2013) assets turnover ratio calculated by taking sales divided by total assets. As explained by Malik and Ali (20I3) firms found to be more efficient in utilizing its assets and generate sales when its assets turnover ratio reported to be high. They also said when the company reported high ratio of asset turnover lead to an increase in company's profit and make the ratio to have positive and significant relationship with share price and this is witnessed in their own study by using a sample of 2I public companies from fuel and energy sector listed in Karachi stock exchange (KSE). Ozlen (20I4) reported total assets turnover ratio to have negative and significant relationship with share price of metal-product and stone sectors listed in Istanbul stock exchange but positive and significant relationship exist with share price of stone sector, metal products sector, transportation sector and commerce sector. 


\subsection{Debt to Equity Ratio}

The debt-to-equity ratio is a financial ratio that shows the relative share of capital and debt used to finance the company's assets; this link is also known as risk, leverage or leverage." Some academics have had an impact on this dividend policy for companies. Companies with high growth rates and high dividend payouts use debt and high-leverage companies compared to their respective industries. However, there is contradictory evidence in the relationship between dividend payment rates and leverage. In some industries, payment rates and leverage are positively linked, while in other industries the ratio is negative. There is a statistically significant and negative relationship between risk and market value of a company. It is clear that higher risk companies pay dividends at a lower rate, which affects the market value of the companies.

\subsection{Dividend per Share}

Dividend per share is the sum of declared dividends issued by a company for every ordinary share outstanding; The figure is calculated by dividing the total dividends paid out by a business, including interim dividends, over a period of time by the number of outstanding ordinary share issued; A company's dividend per share is often derived using the dividend paid in the most recent quarter, which is also used to calculate the dividend yield;Dividend per share is an important metric to investors because the amount a firm pays out in dividends directly translates to income for the shareholder, and the dividend per share is the most straightforward figure an investor can use to calculate his or her dividend payments from owning shares of a stock over time (Pandey, 20I5). At the same time, a growing dividend per share may also be a sign that the company's management believes that its earnings growth will be sustained.

For the correct calculation of dividends per share, including interim dividends, dividends for the entire year, except special dividends, must be included; Special dividends are dividends that are expected to be issued only once and are therefore not included; Temporary dividends are dividends distributed to shareholders that have been declared and paid before the enterprise has determined its annual profit; If an entity has issued ordinary shares during the calculation period, the total number of ordinary shares outstanding is calculated over the reporting period on the basis of the weighted average number of shares, which is the same as that used for the share.

\subsection{Theoretical Review}

The theoretical approach to the relationship between financial accounting information and equity share investment can be discussed in terms of, accounting theories and theory of equity share investment. There are many financial accountingtheories. Theories of financial accounting consider such things as people's behavioror people's needs as regards financial accounting information, or the reasonswhy people within organizations might elect to supply particular information toparticular stakeholder groups (Deegan, 2006). This study looks at Efficient-market hypothesis (EMH), information perspective theory, accounting theory, decision usefulness theory of accounting information and signaling theory ofaccounting information among others theories.

\subsection{Efficient Market Hypothesis}

Efficient-market hypothesis (EMH) asserts that financial market is informationally efficient. There are three major forms of the hypothesis: "weak" semi-strong", and "strong". Weak EMH claims that prices on traded assets (for example, stock bonds, or property) already reflect all past publicly available information. Semi-strong EMH states that prices reflect all publicly available information and that prices instantly change to reflect new public information. Strong EMH additionally claims that prices instantly reflect even hidden or "insider" information. Efficient market theory implies that market will react quickly to new information (Goddy, 2010). Thus, it is important to know when the accounting report first became publicly known. The accounting report is informative only if it provides data not previously known by the market.

\subsection{Information Perspective}

Informational perspective measures the usefulness of accounting information to individual users without much emphasis on the precise structure of the relationship between accounting data and firm value (Bernard, 1995). Most of the studies on information perspective assume that information content or usefulness can be determined by observing stock market reactions to specific accounting information items (Ball and Brown, 1968, Benston, 1967 and Anderson, I975). These studies further assert that the degree of usefulness can be measured by the extent of volume or price change following release of the information.

Until the last few years, the information perspective has dominated financial accounting theory and practice. The information perspective relies on a single-person decision theory, where it is the responsibility of an investor to predict future firm performance and make investment decisions. It also depends on efficient securities market theory, where the market can interpret information from any source (Beaver, 1973). In this theory, it is Accountant's role to supply useful financial statement information to assist investors. Ball and Brown (1968) study is the first to document statistically a share price response to reported net income and their methodology is still employed today. The emphasis of information perspective is on 
contemporary associations between accounting earnings (or book value) and market returns or prices. In particular, it investigates capital market reactions to public disclosures such as earnings announcements, other firm-specific news and economy-wide macroeconomic news. This is synonymous with information content school.

\subsection{Accounting Theory}

Accounting theory is defined as the basic assumptions, definitions, principles, and concepts that underlie accounting rule made by a legislative body and it also includes the reporting of accounting and financial information (Deegan, 2006). The basic theories of accounting are held together by the conceptual framework of accounting. The conceptual framework establishes objectives of financial reporting by businesses. By understanding how some basic accounting theories fit into the conceptual framework, one can determine the theoretical underpinnings of financial accounting rules and principles (Freedman, 20I5).

Financial Accounting Standards Board (FASB, 1976) defines accounting theory as acoherent system of interrelated objectives and fundamentals that can lead toconsistent standards. Watts and Zimmerman (1986) posit that accounting theory seeks to explain and predict accounting practice. Hendriksen (I982) describes an accounting theory as logical reasoning in the form of abroad set of principles that (I) provide a general frame of reference by which accounting practice can be evaluated and (2) guide the development of new practices and procedures. According to him, an accounting theory should provide a general frame of reference against which sound accounting practices can be evaluated. A theory encompasses a set of statements or propositions connected by rules of logic or inferential reasoning. The statements must include testable hypotheses or premises and a conclusion, although one or more of the premises may be based on explicit value judgments. The primary test of a theory, however, is its ability to explain or predict (Quintus, 2007).

\section{IO Empirical Review}

Wang et al (2013) empirically analyzes the relationship between accounting information, stock price and investor's decision making with a few accounting information indexes, based on 60 listed companies in Shanghai Stock Exchange for 20II. The results of their study show that a positive relationship exists between accounting information and stock price, and that the accounting information of the listed companies has an important effect on the quoted companies "e stock price and investors' behaviour in the market, but the significant degree varies. Earnings per share and return on equity have the most significant correlation with stock price and investors decisions.

Vijitha and Nimalathasan (20I4) examined the relevance of accounting information such as earning per share (EPS), net assets value per share (NAVPS), return on equity (ROE) and price earnings ratio $(P / R)$ to investors investment decision in listed manufacturing companies in Colombo Stock Exchange (CSE), Sri Lanka. Findings of their research revealed that accounting information has the significant impact on investors ee investment decision and accounting information is significantly correlated with equity share investment decision.

Shehzad and Ismail (20I4) investigated the relevance of accounting information in banking sector of Pakistan. The study employed the pooled regression technique on nineteen private banks from the period of 2008 to 20I2. Their findings showed that earning per share are more value relevant than book value, and that accounting data explains a high proportion of the investor's equity share investment decisions.

Glezakos, Mylonakis, and Kafouros (2012) studied the impact of earnings and book value on the stock prices and investors investment decisions of a sample of 38 companies listed in the Athens Stock Market during the 1996-2008 periods. The results concluded that the joint explanatory power of the above parameters in the formation of stock prices increases over time. The study further claimed that the impact of earnings is diminishing, compared to the book value, while investors strive towards analyzing the fundamental parameters of businesses.

Sanjeet (20II) carried out a study on the determinants of equity share investment decision in India. The study examine the empirical relationship between equity share prices and explanatory variables such as: book value per share, dividend per share, earnings per share, price- earnings ratio, dividend yield, dividend pay-out, size in terms of sale and net worth for the period 1993-94 to 2008-09. The results revealed that earning per share, dividend per share and book value per share has significant impact on the equity share investment decision. Further, results of study indicated that dividend per share and earnings per share being the strongest determinants of equity share investment.

AL- Shubiri (2010) carried out a study of the determinants of equity share investment at Amman Stock Exchange, Jordan. The sample of their study includes the I4 commercial banks of Amman Stock Exchange for the period 2005 -2008. Simple and multiple regression analyses were conducted to find out the relationship between microeconomic factors and the equity investment. The result of the study showed that there is highly positive significant relationship between equity share investment and net asset value per share; market price of stock dividend percentage, gross domestic product, and negative significant relationship on inflation and lending interest rate but not always significant on some years of Amman Stock Exchange in Jordan. 
Suward (2009) investigated the nature of the relationship between accounting numbers and equity share investment in firms listed on the Jakarta Stock Exchange for the period I992-200I. The study used dynamic modeling principles in addition to the more usual cross sectional analysis. The results of this study show that the accompanying equilibrium correlation relationship between equity share investment and book values for firms listed on the Jakarta Stock Exchange (JSX) can often be identified using accounting regressors. The result of the study showed that in Indonesia, compared to similar models estimated using US data, the book value of net assets seems to have a stronger relationship with stock investment. And it was argued that this may be a function of the relative importance of financial statements as a source of information on the JSX.

Kiremu, Galo, Wagala, and Mutegi (2013) conducted study on the effect of annual earnings announcement at the Nairobi Securities Exchange (NSE) by analyzing changes in share prices and trading volumes for the period from 2006 to 2010. Abnormal returns during the event window of $9 \mathrm{I}$ days were determined using the event study methodology employing the market model on data from 5 listed companies. Further, the volume reactions were examined by use of the trading activity ratio (TAR). Inferential and descriptive statistics were used to test for significant effect on TAR and price changes. The results obtained indicate that the abnormal returns and TAR were not significant at 5\% probability level. Thus the NSE is of semistrong efficiency, whereby it is not possible to earn abnormal returns in the NSE using the publicly available information

According to Oyerinde (20II) found little known about the role of accounting information in terms of its ability to explain changes to the security prices and equity share investment of listed companies on the Nigerian Stock Exchange (NSE). Almost all evidence in this area is obtained from the United States or Western European countries which have sophisticated markets compared to most developing countries.

Uwuigbe, Olowe, and Godswill (2012) examined the determinants of share prices in the Nigerian Stock Exchange Market. A total of 30 listed firms in the Nigerian Stock Exchange Market were selected and analyzed for the study using the judgmental sampling technique. The study basically modelled the effects of financial performance, dividend pay-out, and financial leverage on the share price of listed firms operating in the Nigerian stock exchange market using the regression analysis method. The results of the study revealed a significant positive relationship between firms ${ }^{\text {ee }}$ financial performance and the market value of share prices of the listed firms in Nigeria. Consequently, they concluded that firms financial performance, dividend pay-outs, and financial leverage are strong determinants of the market value of share prices, which thus influenced equity share investment decision making in the listed companies in Nigeria.

Pyemo (201I) examined the stock market reaction to annual earnings information releases using data on the Nigerian Stock Exchange. Using the event study method, the speed of reaction of the market to annual earnings informat ion releases for a sample of 16 firms listed on the exchange is tested. Significant abnormal price reactions around earnings announcements suggest the earnings announcements contain value-relevant information. The study found that the magnitude of the cumulative abnormal returns is dominated by significant reactions 20 days before the earnings release date which suggests that a portion of the market reaction may be due to private acquisition and, possibly, abuse of information by insiders. The persistent downward drift of the cumulative abnormal returns, 20 days after the announcements is inconsistent with the efficient markets hypothes is, and therefore suggests that the Nigerian stock market does not efficiently adjust to earnings information for the sample firms within the study period.

Olugbenga and Atanda (2014) examined relationship between financial accounting information and market values of quoted firms in Nigeria examined value relevance of accounting information in the Nigerian Stock Exchange Market with a view to determining whether accounting information has the ability to significantly affect share prices and investors ${ }^{\text {ee }}$ investment decisions in quoted firms. The findings of their study revealed that there is a significant relationship between accounting information and share prices of firms listed on Nigerian Stock Exchange. They asserted that information on earnings, book value, dividend, and cash flows can be used to predict share prices of firms in Nigeria.

Oshodin and Mgbame (2014) conducted a comparative study on the relevance of accounting information in the Nigeria banking and Petroleum sectors. I0 companies where randomly selected from each of these sectors. Data were collected on the Market Price per Share (dependent variable), Earning per Share, Book Value of Equity, and Leverage (independent variables) for the period 2007-20I I, from the annual financial reports of the selected companies. The study hypothesized that there is no difference in the value relevance of accounting information in both the banking and oil and gas sectors. The study compares the value relevance of accounting numbers in these sectors. The study revealed that the earnings per share information is the most considered by investors when deciding the share price and that the financial information in the oil and gas is more relevant compare to the financial information disclosed by companies in the banking sector.

Srinivasan (2012) conducted a study on the determinants of equity share prices in India. The study employs panel data consisting of annual time series data over the period 2006-20I I and cross-section data pertaining to 6 major sectors of the Indian economy. He claims that accounting information data of the industry are essential and immense helpful to investors and analysts in assessing the better stocks that belong to different industry groups. Accounting data provide critical information to shareholders and or investors as far as the company's past performance is concerned, and are used extensively in forecasting future performance and valuations of equity. 
Eleke and Opoku (2013) stated that accounting information released to the general public by firms directly or indirectly has a major influence on investors' perceptions of the business, hence its value and both individual and institutional investors attach great importance to 3 information in the selection of portfolios of equity securities, bonds and other investments This study carried out an investigation into the relationship between accounting information and equity share investment in listed companies in Nigeria with a view to providing accounting information that will aid investors equity share investment decisions.

Override (20II) stated that in the wake of the recent accounting scandals and economic meltdown where billions of naira of investment and retirement wealth has disappeared, the very integrity and survivability of the relevance of accounting information has been called to question.

Mahmoudi, Shirkavand, and Salari (20II) examined the investor's reactions to the announcement of earnings in the Tehran Stock Exchange in Iran. This study investigated the overreaction and under reaction of investors towards positive and negative earnings announcement dividing the sample into two groups. The first group contains firms which increased their EPS more than 5\% rather than the previous EPS announcements. Group 2 contains firms which decreased their EPS more than 5\% in comparison to the latest announcements. The results indicate that there is a statistically significant market reaction on the EPS announcement day. Earnings increases induce a significant positive equity share investors ${ }^{\text {ee }}$ reaction, whereas earning decreases bring about a significant negative equity share investors "e reaction.

Mgbame and Ikhatua (2013) investigated the accounting information and stock volatility in the Nigerian Capital Market. The broad objective of the study is to ascertain whether accounting information contributes to stock volatility in the Nigerian Capital Market. Specifically, the study examines if Book value per share, Dividend per share and Earnings per share have a sign effect on stock volatility in Nigeria. The results of the study show that the release of information on book values, earnings per share and dividend per share is found to be related to stock volatility.

Glezakos et al (2012) examined the impact of earnings and book value in the formulation of stock prices and stock investors decisions. Using a sample of 38 companies listed in the Athens Stock Market during the 1996-2008 period, the results of the study suggests that the joint explanatory power of the above parameters in the formation of stock prices increases over time. However, they argued that the impact of earnings is diminishing, compared to the book value, while investors strive towards analyzing the fundamental parameters of businesses.

Olugbenga and Atanda (2014) explored the functional relationship between earnings, book values, dividends, cash flow and equity share investment decisions in Nigeria. They found that accounting information, earnings, book values, dividends, cash flow from operations, has a direct/positive relationship with equity share investment decisions in Nigeria. They argued that earnings, book values, dividends, cash flow from operations, are statistically significant in explaining variations in equity share investors' behaviours at 5\% level of significance. Furthermore, they analyzed empirically the relationship between book values and equity share investment decision and from the results concluded that accounting information on book values has a positive relationship with equity share investment decisions in Nigeria.

Babalola (2012) investigated the relevance of accounting information in corporate Nigeria . The study employed simple descriptive statistics coupled with the logarithmic regression models to examine this interaction between the period I 999 and 2009, and taking 40 companies from various sectors of the Nigerian economy as samples. The results of the study shows that earnings is more relevant than book values, that is, the earnings dictates more the corporate values of firms in Nigeria than the book value. Notwithstanding the importance of net book value per share in equity share investment decision makings, the book value per share may be manipulated by company management with a view to presenting favourable value of the company worth. Net book value per share may be manipulated by slowing down depreciation of assets, writing back of depreciation, fraudulent upward revaluation of assets, buying back of owned share and inclusion of outdate equipments in the company's asset. Given these situations, the net book value will give an improvement rate which will be misleading to investors for investment decision makings.

Perrera and Thrikawala (2010) conducted an empirical study of the Relevance of Accounting Information on investor's decisions based on the Colombo Stock Exchange, Sri Lanka. The relevance of accounting data was measured by correlation coefficient with Market Price per Share (MPS) and selected accounting information such as earning per share (EPS), return on equity (ROE) and earning yield (EY). The findings claim that return on equity is significantly related with the share price and investor's decisions.

Wang et al (2013) carried out a study on the accounting information and investors reaction in Shanghai Stock Exchange, and reported that correlation analysis and regression analysis of accounting information and investors reaction show that the accounting information has some effect on equity investors' reaction and stock price, but the significance diversified. They claimed that accounting information of rate of return on stockholders' equity are most significant and that it has direct impact on investors decisions and share price. 
Kabajeh et al (2012) examined the relationship between the return on equity( ROE) ratio and Jordanian insurance public companies share prices and equity share investors reactions during the period (2002-2007). The results of their study showed a positive relationship between the ROE ratio and Jordanian insurance public companies share prices. The results also revealed that equity share investors' decisions are positively influenced by the return on equity.

Uthman and Abdul-Baki (20I4) investigated the effect of IFRS adoption on the value-relevance of accounting information in Nigeria. The IFRS was measured with more disclosure of economic events as well as the fair valuation of economic events under IFRS. The opinions of a number of financial analysts with were sourced. The results of the study show that IFRS adoption has enhanced the value relevance of accounting information in Nigeria. They recommend that more measures should be put in place to ensure full compliance of IFRS by all affected Nigerian entities.

Adebimpe and Ekwere (2015) empirically examined whether the mandatory adoption of IFRS has improved the value relevance of financial information in the financial statements of commercial banks in Nigeria. The study considered a sample of twelve listed banks in Nigeria. Specifically, financial statement figures of 2010 and 201 I (pre-adoption period) and 2012 and 2013 (post-adoption) were utilized. Descriptive statistics and least square regression were conducted to analyze the effect of IFRS adoption on the accounting information quality. The findings reveal that adoption of IFRS (accounting regulation) made earnings reported by Nigerian Commercial banks to become more informative to equity investors in determining the value of banks and that equity value and earnings of banks are relatively value relevant to share prices. The study submits that adopting the International Financial Reporting Standard (IFRS) have been empirically found to improve the quality of accounting information in some countries, thereby increasing its usefulness to stakeholders and recommends that Financial Reporting Council of Nigeria and other accounting standards setters should incorporate more measures to enhance the quality of the financial reporting in order to increase the value relevance of financial statements.

Olawale (20I4) examined the impact of International Financial Reporting Standard (IFRS) adoption on Banks performance in Nigeria. The study is based on the appraisal of IFRS compliance and Adoption. Both primary and secondary data were used in this study. The result of the analysis showed that adoption of IFRS significantly influenced financial reporting of banks in Nigeria and that there is significant relationship between IFRS and banks performance in Nigeria.

Tsalavoutas, Andre, and Evans, (2012) examined the combined value relevance of book value of equity and net income before and after the mandatory transition to IFRS in Greece. Contrary to their expectations, they find no significant change in the explanatory power of value relevance regressions between the two periods. The coefficients on book value of equity and net income are positive and significant in both the pre-IFRS and post-IFRS periods.

\section{Methodology}

This study used correlation and ex-post facto research design to examine the effect of accounting information on market value of quoted in Nigeria. The population of this study consists of all the listed manufacturing firms on the Nigerian Stock Exchange and have complete financial records on their websites or Nigerian Stock Exchange for the period of 2008- 2017. The data was obtained from the annual reports and accounts of manufacturing firms.

\section{Model Specification}

In order to achieve the objectives of this study and test of the hypotheses, a functional relationship in form of multiple linear regression model consisting of dependent and independent variables will be formulated. The regression models are presented as follows;

\section{Pooled regression specification}

$$
M V=\beta_{0}+\beta_{1} A T O_{i t}+\beta_{2} D E R_{i t}+\beta_{3} D P S_{i t}+\mu_{i t}
$$

\section{Fixed Effect Model Specification}

$M V=\alpha_{0}+\alpha_{1 \text { ATO }}+\alpha 2 D E R+\alpha_{3} D P S+\sum_{i}^{3}=1 \alpha_{i} i d u m \varepsilon 1_{i t}$

\section{Random effect model specification}

$M V=\alpha_{0}+\alpha_{1} A T O+\alpha 2 D E R+\alpha_{3} D P S+\mu i+\varepsilon 1_{i t}$

Where:

MV = Market value of Nigeria quoted manufacturing firms.

$\beta_{0}=$ Regression intercept

$\mathrm{ATO}=$ Assets turnover ratio

$\mathrm{DER}=$ Debt equity ratio 
$\begin{array}{lll}\text { DPS } & = & \text { Dividend per share } \\ \boldsymbol{\mu} & = & \text { Error term }\end{array}$

\section{A-Priori Expectation of the Result}

The explanatory variables are expected to have positive and direct effects on the dependent variables. That is a unit increase in any of the variables is expected to increase market value. This can be express mathematically as $\beta_{\text {I, }} \beta_{2}, \beta_{3,}>0$.

\section{Technique for Data Analysis}

In order to determine the best choice of analysis technique, the study run three types of regression; Ordinary Least Square (OLS), Fixed Effect and Random Effect regression. All these method have various assumptions and conditions that must be fulfilled in order to achieve efficient estimates. However, the best techniques will be decided by the Hausman Specification test (either fixed effect or random effect regression) and Lagrangian Multpiplier Test (either random effect or OLS). The random effect has the advantage of accounting for the panel effect in the data as opposed to OLS, which pools the data and treats it as if it were obtained from a single entity. In order to achieve reliability of the result, robustness tests like Multicolinearity test, Hausman test, Lagrangian multiplier test for random effect and Heteroscedasticity test will be conducted(Gujirati, 2003).

T-test The t-test was used to test the hypothesis that a particular coefficient is significantly different from zero or whether the estimated coefficient value occurred by chance in equation (2). The tests were performed at both $95 \%$ and $99 \%$ levels of confidence.

F-test The F-statistic is important to test the hypothesis that the whole relationship provided by the equation (2) is significantly different from zero, i.e. whether the independent variables' characteristics scores explain the variation in growth indicators for each of the individual firms. The test will be performed at both $95 \%$ and $99 \%$ levels of confidence.

$R 2$ - Change The R-squared ( $R^{2}$ ) value ranging from ' $O$ ' to ' $I$ ' or the 'corrected R-squared' (R2 ) which is adjusted for degrees of freedom indicates the explanatory power (goodness of fit) of the model.

\section{Analysis and Discussion of Findings}

Table I: Test of Fixed and Random Effect Models

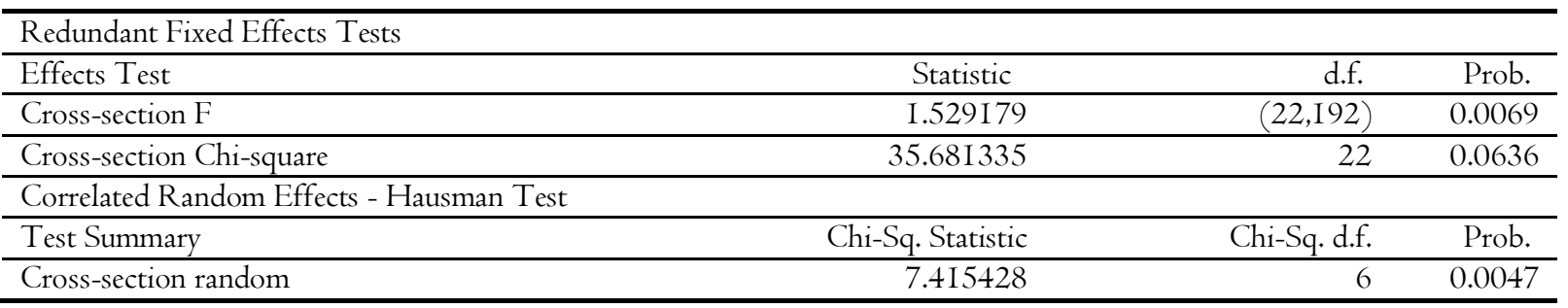

Source: Computed from E-View windows 9.0

In testing the validity of the models, the fixed effects on the cross section Redundant Fixed Effect- Likelihood Ratio, the Pvalue is 0.000 indicating that the effects are significant. Select the random effect and perform the Correlated Random EffectsHausman test, testing the random effects model against the fixed effects model. The null hypothesis in that case is that both tests are consistent estimators and the random effects model is efficient. Under the alternative hypothesis, only the fixed effect is consistent. Since the p-value is 0.000 , the null hypothesis is rejected and, therefore, the fixed effects model is to be preferred.

Table 2:Presentation of Formulated Pooled Effect Model Results

\begin{tabular}{cccrr}
\hline \multicolumn{1}{c}{ Variable } & Coefficient & Std. Error & t-Statistic & Prob. \\
\hline DER & 0.031910 & 0.020106 & I.587099 & 0.1 I40 \\
\hline ATO & 0.048064 & 0.047975 & I.001859 & 0.3175 \\
\hline BVPS & -0.061550 & 0.067609 & -0.910373 & 0.3636 \\
\hline C & 9.953181 & I.835I72 & 5.423568 & 0.0000 \\
\hline R-squared & 0.086439 & Mean dependent var & & I4.939I4 \\
\hline Adjusted R-squared & 0.074935 & S.D. dependent var & 2.146708 \\
\hline S.E. of regression & 2.121677 & Akaike info criterion & 4.373452 \\
\hline Sum squared resid & 963.3238 & Schwarz criterion & & 4.481087 \\
\hline
\end{tabular}




\begin{tabular}{lclr}
\hline Log likelihood & -476.2665 & Hannan-Quinn criter. & 4.416913 \\
\hline F-statistic & I.870285 & Durbin-Watson stat & 1.662720 \\
\hline Prob(F-statistic) & 0.087183 & & \\
\hline
\end{tabular}

Source: Computed from E-View windows 9.0

The estimated pooled regression model found that the predictor variables in the model can explain 8 percent variation on the market value of the 23 selected manufacturing firms. The f-statistics and probability confirms that the model is statistically not significant and cannot predict the variation on the market value of the selected quoted firms. The Durbin Watson statistics proved that there is no presence of serial autocorrelation among the variables. Beta coefficient of the variables indicates that debt equity ratio and assets turnover rate have positive effect on market value of the quoted manufacturing firms while book value per share have negative effect on market value of the firms. The insignificant effect of the models and the results of the Hausman test enable us to analyze the fixed effect model in the tables below.

Table 3:Presentation of Formulated Fixed Effect Model Results

\begin{tabular}{|c|c|c|c|c|}
\hline Variable & Coefficient & Std. Error & t-Statistic & Prob. \\
\hline DER & 0.722684 & 0.021505 & I.05486I & 0.0428 \\
\hline ATO & 0.032115 & 0.050056 & 0.641582 & 0.5219 \\
\hline BVPS & -0.030528 & 0.076752 & -0.397752 & 0.6913 \\
\hline $\mathrm{C}$ & $\mathrm{I} 2.36263$ & $2.0949 \mathrm{II}$ & 5.901265 & 0.0000 \\
\hline \multicolumn{5}{|c|}{ Effects Specification } \\
\hline \multicolumn{5}{|c|}{ Cross-section fixed (dummy variables) } \\
\hline R-squared & 0.789574 & Mean dependent var & & $\mathrm{I} 4.939 \mathrm{I} 4$ \\
\hline Adjusted R-squared & 0.504834 & S.D. dependent var & & 2.146708 \\
\hline S.E. of regression & 2.066219 & Akaike info criterion & & 4.411093 \\
\hline Sum squared resid & 819.6977 & Schwarz criterion & & 4.857006 \\
\hline Log likelihood & -458.4258 & Hannan-Quinn criter. & & 4.591145 \\
\hline F-statistic & $\mathrm{I} .624076$ & Durbin-Watson stat & & 1.905250 \\
\hline Prob(F-statistic) & 0.000169 & & & \\
\hline
\end{tabular}

Source: Computed from E-View windows 9.0

The estimated pooled regression model found that the predictor variables in the model can explain 78 percent variation on the market value of the 23 selected manufacturing firms. The f-statistics and probability confirms that the model is statistically not significant and cannot predict the variation on the market value of the selected quoted firms. The Durbin Watson statistics proved that there is no presence of serial autocorrelation among the variables. Beta coefficient of the variables indicates that debt equity ratio and assets turnover rate have positive effect on market value of the quoted manufacturing firms while book value per share have negative effect on market value of the firms. The insignificant effect of the models and the results of the Hausman test enable us to analyze the fixed effect model in the tables below.

Table 4:Presentation of Formulated Random Effect Model Results

\begin{tabular}{|c|c|c|c|c|}
\hline Variable & Coefficient & Std. Error & t-Statistic & Prob. \\
\hline DER & $0.02901 \mathrm{I}$ & 0.020108 & 1.442768 & 0.0005 \\
\hline ATO & 0.044351 & 0.047723 & 0.929330 & 0.3538 \\
\hline BVPS & -0.055560 & 0.068658 & -0.809227 & 0.4193 \\
\hline $\mathrm{C}$ & 10.52168 & 1.866897 & 5.635922 & 0.0000 \\
\hline \multicolumn{5}{|c|}{ Effects Specification } \\
\hline & & & S.D. & Rho \\
\hline Cross-section random & & & 0.472147 & 0.0496 \\
\hline Idiosyncratic random & & & 2.066219 & 0.9504 \\
\hline \multicolumn{5}{|c|}{ Weighted Statistics } \\
\hline R-squared & 0.441900 & Mean dependent var & & 12.18603 \\
\hline Adjusted R-squared & 0.315038 & S.D. dependent var & & 2.096432 \\
\hline S.E. of regression & 2.072931 & Sum squared resid & & 919.5673 \\
\hline F-statistic & I.55980I & Durbin-Watson stat & & 1.726119 \\
\hline
\end{tabular}




\begin{tabular}{llll}
\hline Prob(F-statistic) & 0.040262 & & \\
\hline & \multicolumn{2}{c}{ Unweighted Statistics } & \\
\hline R-squared & 0.448637 & Mean dependent var & I4.939I4 \\
\hline Sum squared resid & 964.5282 & Durbin-Watson stat & I.6583I6 \\
\hline
\end{tabular}

Source: Computed from E-View windows 9.0

The estimated random regression model found that the predictor variables in the model can explain 44 percent variation on the market value of the 23 selected manufacturing firms. The f- statistics and probability confirms that the model is statistically significant and can predict the variation on the market value of the selected quoted firms. The Durbin Watson statistics proved that there is no presence of serial autocorrelation among the variables. Beta coefficient of the variables indicates that, return on equity, earnings per share, dividend per share, debt equity ratio and assets turnover rate have positive effect on market value of the quoted manufacturing firms while book value per share have negative effect on market value of the firms. The result above enables to test cross-sectional comparism of random and fixed effect in the table below:

Table 5: Cross-Section Effect Test Comparism

\begin{tabular}{|c|c|c|c|c|c|c|}
\hline Variable & Fixed & & Random & Var. Diff & Prob. & Decision \\
\hline DER & & 0.022684 & 0.029011 & 0.000058 & 0.4067 & Accept $\mathrm{H}_{0}$ \\
\hline ATO & & 0.032115 & $0.04435 \mathrm{I}$ & 0.000228 & 0.4179 & Accept $\mathrm{H}_{0}$ \\
\hline BVPS & & -0.030528 & -0.055560 & 0.001177 & 0.4656 & Accept $\mathrm{H}_{0}$ \\
\hline
\end{tabular}

Source: Computed from E-View windows 9.0

The table above reveals the variance difference among the variables, as shown above that the variables are all statistically not significant which implies that there is a significant difference between fixed and random effect among the variables.

Table 6: Presentation of Granger Causality Test Results

\begin{tabular}{lccc}
\hline Null Hypothesis: & Obs & F-Statistic & Prob. \\
\hline DER does not Granger Cause MV & I68 & 0.21023 & 0.8106 \\
\hline MV does not Granger Cause DER & & 2.59882 & 0.0774 \\
\hline ATO does not Granger Cause MV & I70 & 1.45459 & 0.2365 \\
\hline MV does not Granger Cause ATO & & 2.30013 & 0.1035 \\
\hline BVPS does not Granger Cause MV & 170 & 0.00118 & 0.9988 \\
\hline MV does not Granger Cause BVPS & & 0.25433 & 0.7757 \\
\hline
\end{tabular}

Source: Computed from E-View windows 9.0

The causality test above shows that there is no causal relationship among the variables, we accept null hypotheses.

Table 7: Presentation of Panel Cointegration Test

\begin{tabular}{|c|c|c|c|c|}
\hline Series: MV DER ATC & & & & \\
\hline Alternative hypothesis & fs. (within-d & & & \\
\hline & & & Weighted & \\
\hline & Statistic & Prob. & Statistic & Prob. \\
\hline Panel v-Statistic & -2.429724 & 0.9924 & -2.299783 & 0.9893 \\
\hline Panel rho-Statistic & 4.640154 & 1.0000 & $4.54819 \mathrm{I}$ & 1.0000 \\
\hline Panel PP-Statistic & -3.186873 & 0.0007 & -3.047196 & 0.0012 \\
\hline Panel ADF-Statistic & NA & NA & NA & NA \\
\hline Alternative hypothesis & efs. (betweer & & & \\
\hline & Statistic & Prob. & & \\
\hline Group rho-Statistic & 6.156503 & 1.0000 & & \\
\hline Group PP-Statistic & -9.556352 & 0.0000 & & \\
\hline Group ADF-Statistic & NA & NA & & \\
\hline
\end{tabular}

Source: Computed from E-View windows 9.0 
The results of the cointegration test proved that the variables are cointegrated as the probability coefficient of the variables are less than 0.05, we accept the alternate hypotheses that there is the presence of long run relationship between the dependent and the independent variables. The presence of long run relationship enables us to test for unit root; the table below has the details.

Table 8:Tests of Stationarity

\begin{tabular}{|c|c|c|c|c|c|c|}
\hline \multicolumn{7}{|l|}{ Series: MV } \\
\hline Method & \multicolumn{3}{|c|}{ Statistic } & Prob. & sections & Obs \\
\hline \multicolumn{7}{|c|}{ Null: Unit root (assumes common unit root process) } \\
\hline Levin, Lin \& Chu $t^{* \pi}$ & \multicolumn{3}{|c|}{-9.25205} & 0.0000 & 23 & 170 \\
\hline Im, Pesaran and Shin W-stat & \multicolumn{3}{|c|}{-3.15566} & 0.0008 & 23 & 170 \\
\hline ADF - Fisher Chi-square & \multicolumn{3}{|c|}{86.3823} & 0.0003 & 23 & 170 \\
\hline PP - Fisher Chi-square & \multicolumn{3}{|c|}{$\mathrm{I} 45.244$} & 0.0000 & 23 & 197 \\
\hline \multicolumn{7}{|l|}{ Series: $\mathrm{D}(\mathrm{DER})$} \\
\hline Levin, Lin \& Chu $\mathrm{t}^{*}$ & -22.8587 & \multicolumn{2}{|l|}{0.0000} & \multicolumn{2}{|r|}{23} & I59 \\
\hline Im, Pesaran and Shin W-stat & -8.51342 & \multicolumn{2}{|l|}{0.0000} & \multicolumn{2}{|r|}{23} & 159 \\
\hline ADF - Fisher Chi-square & I50.519 & \multicolumn{2}{|l|}{0.0000} & \multicolumn{2}{|r|}{23} & I59 \\
\hline PP - Fisher Chi-square & 343.638 & \multicolumn{2}{|l|}{0.0000} & \multicolumn{2}{|r|}{23} & 182 \\
\hline \multicolumn{7}{|l|}{ Series: BVPS } \\
\hline Levin, Lin \& Chu t ${ }^{\text {*x }}$ & \multicolumn{2}{|c|}{-6.67509} & 0.0000 & & 23 & I84 \\
\hline Im, Pesaran and Shin W-stat & \multicolumn{2}{|c|}{-3.05967} & $0.001 \mathrm{I}$ & & 23 & 184 \\
\hline ADF - Fisher Chi-square & \multicolumn{2}{|c|}{83.0036} & 0.0007 & & 23 & I84 \\
\hline PP - Fisher Chi-square & \multicolumn{2}{|c|}{156.215} & 0.0000 & & 23 & 207 \\
\hline \multicolumn{7}{|l|}{ Series: ATO } \\
\hline Levin, Lin \& Chu $\mathrm{t}^{* *}$ & \multicolumn{2}{|c|}{-5.96046} & 0.0000 & & 23 & 184 \\
\hline Im, Pesaran and Shin W-stat & \multicolumn{2}{|c|}{-3.37459} & 0.0004 & & 23 & I84 \\
\hline ADF - Fisher Chi-square & \multicolumn{2}{|c|}{88.9042} & 0.0002 & & 23 & 184 \\
\hline PP - Fisher Chi-square & \multicolumn{2}{|c|}{190.177} & 0.0000 & & 23 & 207 \\
\hline
\end{tabular}

Source: Computed from E-View windows 9.0

The table above presents the summary results of the ADF and PP panel unit root tests. The results show that the null hypotheses of a unit root test for first difference series for all the variables can be rejected at all the critical values indicating that the level series which is largely time-dependent and non-stationary can be made stationary at the first difference and maximum lag of one. Thus, the reduced form model follows an integrating order of $\mathrm{I}(\mathrm{I})$ process and is therefore a stationary process. It also reveals that the test of stationarity in the residuals from the level series regression is significant at all lags. Furthermore, this indicates that the regression is no more spurious but real. That is to say, all the variables are individually stationary and stable. At this level, all the t-statistic became significant at 5 percent.

Table9:Phillips-Peron Results (Non-Parametric)

\begin{tabular}{|c|c|c|c|c|c|}
\hline Cross ID & $\operatorname{AR}(I)$ & Variance & HAC & Bandwidth & Obs \\
\hline Aluminium Extrusion & -0.161 & 0.646540 & 0.619755 & 2.00 & 9 \\
\hline Austin Laz and Company & -0.843 & 0.083477 & 0.064919 & 1.00 & 9 \\
\hline Paints and Coatings & 0.013 & 2.090620 & 1.597237 & 3.00 & 9 \\
\hline Berger Paints & & from Test & & & \\
\hline Beta Glass & & from Test & & & \\
\hline Cadbury Nigeria & -0.475 & 0.300930 & 0.049049 & 8.00 & 9 \\
\hline Cement Co. of North & & from Test & & & \\
\hline Champion Brew. Plc & -0.229 & 0.968705 & 0.574934 & 6.00 & 9 \\
\hline Premier Paints Plc & & from Test & & & \\
\hline Dangote Cement Plc & -0.447 & 0.455981 & 0.210542 & 4.00 & 9 \\
\hline Dangote Flour Mills Plc & 0.260 & 0.517686 & 0.507708 & $\mathrm{I} .00$ & 9 \\
\hline DN Tyre \& Rubber Plc & -0.249 & 1.806874 & 1.806874 & 0.00 & 9 \\
\hline Evans Medical Plc & & from Test & & & \\
\hline Flour Mills Nig. Plc & & from Test & & & \\
\hline
\end{tabular}




\begin{tabular}{|c|c|c|c|c|c|}
\hline P Z Cussons Nigeria Plc & -0.618 & 0.295691 & 0.223230 & 2.00 & 9 \\
\hline Vitafoam Nig Plc & $-0.10 \mathrm{I}$ & 0.232916 & 0.216321 & 4.00 & 9 \\
\hline $\begin{array}{c}\text { Glaxo Smithkline Consumer } \\
\text { Nig. Plc }\end{array}$ & -0.442 & 0.099122 & 0.048300 & 8.00 & 9 \\
\hline Honeywell Flour Mill Plc & -0.738 & 0.480678 & 0.169825 & 5.00 & 9 \\
\hline Lafarge Africa Plc & & from Test & & & \\
\hline Nestle Nigeria Plc & & from Test & & & \\
\hline May \& Baker Nigeria Plc & 0.054 & I.I7I200 & 0.428968 & 8.00 & 9 \\
\hline Flour Mills Plc. & -0.432 & 0.064481 & 0.064481 & 0.00 & 9 \\
\hline Nascon Allied Industries & -0.396 & 0.259262 & 0.251736 & 1.00 & 9 \\
\hline
\end{tabular}

Source: Computed from E-View windows 9.0

The result of the power for all the test procedure when the underlying time series model is stationary AR, all the procedures produced a reasonably high power over all the sample sizes and order considered except at order 2 where ADF (Augmented Dickey Fuller) and KPSS produced extremely low power compared to PP. Under this condition, Philip-Peron (PP) has the highest power over all the sample sizes and AR orders considered. The table presents similar analysis on stationary MA, the power of the tests are extremely high over all the sample sizes and orders considered. Similar conclusion as in AR was also observed here. Table 3 presents the power of the mixed model (Stationary ARMA), all the test procedures produced high power over all the sample sizes at order I but ADF and KPSS produced low power over all the sample size at order $2 \& 3$.

\section{I Discussion of Findings}

Findings revealed that there is positive but not significant relationship between assets turnover rate and the market value of the quoted manufacturing firms over the periods covered in this study. This implies that variation in assets turnover rate of the firms does significantly relate to market value of the firms. The coefficient of the variables proved that a unit increase on the variables will lead to 0.3 percent increase on the market value. This finding confirms the a-priori expectation of the study and validates the fundamentalists' theory on the effect of information on the stocks prices of quoted firms. The findings of this study contradict the findings of King and Langli (1998) that both the book value and the earnings per share have significant relation with the stock price and hence equity investment decision, the findings of Omoye, and Eriki, (2014) balance sheet information has significant positive influence on the probability of companies that adopt high earnings management but contradict the findings of Muhammed (20I4) that board composition, institutional shareholding, managerial shareholding and audit committee significant negative relationship with earnings quality.

Findings revealed that there is positive and significant relationship between assets turnover rate and the market value of the quoted manufacturing firms over the periods covered in this study. This implies that variation in debt equity rates of the firms does significantly relate to market value of the firms. The coefficient of the variables proved that a unit increase on the variables will lead to 7 percent increase on the market value. This finding confirms the a-priori expectation of the study and validates the fundamentalists' theory on the effect of information on the stocks prices of quoted firms. The findings of this study contradict the findings of King and Langli (1998) that both the book value and the earnings per share have significant relation with the stock price and hence equity investment decision, the findings of Omoye, and Eriki, (20I4) balance sheet information has significant positive influence on the probability of companies that adopt high earnings management but contradict the findings of Muhammed (2014) that board composition, institutional shareholding, managerial shareholding and audit committee significant negative relationship with earnings quality.

Findings revealed that there is positive and significant relationship between dividend per share and the market value of the quoted manufacturing firms over the periods covered in this study. This implies that variation in dividend per share of the firms significantly relate to market value of the firms. The coefficient of the variables proved that a unit increase on the variables will lead to 9 percent increase on the market value. This finding confirms the a-priori expectation of the study and validates the fundamentalists' theory on the effect of information on the stocks prices of quoted firms. The findings of this study contradict the findings of King and Langli (1998) that both the book value and the earnings per share have significant relation with the stock price and hence equity investment decision, the findings of Omoye, and Eriki, (20I4) balance sheet information has significant positive influence on the probability of companies that adopt high earnings management but contradict the findings of Muhammed (2014) that board composition, institutional shareholding, managerial shareholding and audit committee significant negative relationship with earnings quality.

\section{Conclusions}

The results of study through secondary data analysis revealed that accounting information and market value are correlated and there is a strong and significant relationship between accounting information disclosed in firms' financial statements and market 
value. Accounting information significantly influenced market value decisions in the listed companies in Nigeria. This finding was substantiated by the $\mathrm{R}^{2}$ of 78 percent variation explained by the accounting information variables modeled in the study. The results of the investigation revealed that there is a strong relationship between accounting information and market value of the quoted firms

All accounting information variables considered in this study significantly influenced market value of the quoted firms. Further, results of study indicated that debt equity ratio, assets turnover significantly affect market value of the quoted firms. However, dividend per share has no significant effect. From the above, this study conclude that accounting information have significant effect on the market value of quoted firms in Nigeria.

\section{Recommendations}

Base on the findings of the study, the following recommendations are formulated:

- Management of the firms should formulate dividend policy that will enhance the market value of the firms an optimal capital structure should be formulated and corporate strategies toward internal and external factors that affect Earnings per Share negatively of the manufacturing firms should be discouraged in the firms and factors that affect positively should be encouraged.

- Accounting regulatory bodies in Nigeria and preparers of accounting reports should make efforts toward improving the quality of published financial reports because the reports are widely used by investors in Nigeria and foreign investors for investment decision.

- The study found positive relationship between assets turnover and market value, therefore corporate strategies should be toward internal and external factors that affect assets turn negatively of the manufacturing firms should be discouraged in the firms and factors that affect positively should be encouraged.

\section{References}

Adaramola, A. O. (20I4). The relationship between financial accounting information and market values of quoted firms in Nigeria. Global Joumal of contemporary research in accounting, Auditing and Business Ethics, I (I), 22-39.

Adaramola, A. O., \& Oyerinde, A. A. (20I4). The relationship between financial accounting information and market values of quoted firms in Nigeria. Global Journal of Contemporary Research in Accounting, Auditing and Business Ethics (GJCRA), I(I), $22-30$.

Adebimpe, O. U., \& Ekwere, R. E. (2015). IFRS adoption and value relevance of financial statements of Nigerian Listed Banks. International Journal of Finance and Accounting, 4(I), I-7

AL- Shubiri, F. N. (2010). Analysis the determinants of market stock price movements: an empiric al study of Jordanian Commercial Banks. International Joumal of Business and Management, 5(10), I37-I47.

American Accounting Association (1977).Committee on concepts and standards for external financial reports. Statement on Accounting Theory and Theory Acceptance. American Accounting Association.

Amihud, Y. \& Mendelson, H. (1986). Asset pricing and the bid-ask spread. Journal of Financial Economics, I7(2), $223-249$.

Babalola. A. Y. (2012). Significance of accounting information on corporate value of firms in Nigeria. Research Journal in Organization Psychology and Education Studies, I(2), I05-II3.

Ball, R. (200I): Infrastructure requirements for an economically efficient system of public financial reporting and disclosure. Bookings- Wharton Papers On Financial Services.

Beaver, W. H. (I968). Market prices, financial ratios and the prediction of failure. Journal of Accounting Research, I79-I92.

Beaver, W. H. (1968): The information content of annual earnings announcements. Journal Of Accounting Research( Empirical Research In Accounting: Selected Studies) 67-92.

Bernard, V. L. \& Skinner, D. J. (I996). What motivates managers' choice of discretionary accruals? Journal of Accounting and Economics 22 (I/3), 313-325.

Beuselinck, C. (2005). Essays on financial reporting quality, earning management, and corporate disclosure. University of Ghent, Ghent, Belgium.

Black B. (2000): Legal and institutional preconditions for strong stock market. Working paper, John M Olin Program in Law and Economics, Stanford Law School.

Capital Market: A Garch Analysis Approach. International Review of Management And Business Research 2(I),90-II7.

Choi, B., Collins, D. \& Johnson, W. (I997). Valuation implications of reliability differences: the case of non-pension postretirement obligations. The Accounting Review, 72, 35I-383.

Choi, F. D. S. I973. Financial disclosure and entry to the European capital market. Journal of Accounting Research (Autumn): I59-I75.

Christian, C. (2004). The value-relevance of earnings and operating cash flows during mergers. Managerial Finance, 30 (II): I6-29. 
Deegan .C. (2006). Introduction to financial accounting theory. New York: McGraw-Hill.

Deegan, C. (2002). The legitimising effect of social and environmental disclosures : A theoretical foundation. Accounting Auditing \& Accountability Joumal I5(3):282-3II.

Diamond D. W. and Verrecchia R. E. (I987): Constraints on short selling and asset price adjustment to private information. Journal of Financial Economics I8, 272-3II.

Diamond, D., \& Verrecchia, R. (I99I). Disclosure, liquidity, and the cost of capital. The Journal of Finance, 46(4), pp. I325I355.

Eleke-Aboagye, P.Q., \& Opoku, E. (2013). The effect of earnings announcement on share prices in Ghana: A Study of Ghana Stock Exchange. Research Journalof Finance and Accounting, 4(I7), I66 -I86.

FASB. (I998). Objectives of financial reporting by business enterprises: statement of financial accounting concepts. No. I Stamford, CT: Financial Accounting Standards Board. Review of Accounting Studies, 8 (2-3): 221 - 243.

Freedman, J. (2015). What Are the Basic Accounting Theories? Demand Media.

Germon, H., \& Meek, G.K. (200I). Accounting: an international perspective. McGraw Hill: Singapore.

Glezakos, M., Mylonakis, J., \& Kafouros, C. (2012). The impact of accounting information on stock prices: evidence from the Athens stock exchange. International Journal of Economics and Finance, 4(2), 56-68.

Goddy, E.(2010).Suspension of firms: a timely intervention. Market Report. Lagos: This day Newspaper.

Gujarati, N. D. \& Dawn, C. P. (2009). Essentials of econometrics. McGraw-Hill/Irwin, New York. Fifth Edition.

Gupta, S.C. (20I I). Fundamentals of Statistics. New Delhi, Himalayo Publishing House PVT Ltd.

Healy, P.M. \& Williston, J.R. (2005). The challenges facing auditors and analysts in U.S. capital markets. Lecture series of Business Administration Harvard Business School Harvard University. Working Paper.

Healy, P.M., \& Palepu, K.G. (200I). Information asymmetry, corporate disclosure, and the capital markets: a review of the empirical disclosure literature. Journal of Accounting and Economics, 3I(I/3), pp. 405-440.

Healy,P.M., \& Wahlen, J.M. (I999). A review of the earnings management literature and its implication for standard settings. Accounting Horizons, 13, 365-383 I26.

Hendriksen, E. (1970). Accounting theory. Illinois: Richard D. Irwin.

Kabajeh, Nu'aimat \& Dahmash. (20I2). The relationship between the roa, roe and roi ratios with Jordanian insurance public companies market share price. International Journal of Humanities and Social Science, 2(II) II5 - I2O.

King, R. D., \&Langli, J. C. (1998).Accounting diversity and firm valuation. The International Journal of Accounting, 33, 529567.

Kiremu, M. K.G., Galo, N., Wagala, A., \&Mutegi, J. K. (2013).Stock price and volumes reaction to annual earnings announcement: a case of the Nairobi securities exchange. International Journal of Business, Humanities and Technology, (3(2), I00 -III.

Lang, M. and Lundholm (1993): Cross-sectional determinants of analyst ratings of corporate disclosures. Journal of Accounting Research, 246-27I.

Lindblom, C.K. (1994). The implications of organizational legitimacy for corporate social performance and disclosure. Critical Perspectives on Accounting Conference. New York.

Mahmoudi, V., Shirkavand, S., \& Salari, M. (20II). How do investors react to the Earnings Announcements. International Research Journal of Finance and Economics, 70, I45-152.

Mahmoudi, V., Shirkavand, S., \& Salari, M. (20I4). How do investors react to the earnings announcements. International Research Journal of Finance and Economics, 70.

Mgbame, C. O., \& Ikhatua, O. J. (2013). Accounting information and stock volatility in the Nigerian capital markets: a GARCH analysis approach. International Review of Management and Business Research, 2.

OECD. (2002). Glossary of key terms in evaluation and results based management. Development Co-operation Directorate, OECD Publications, Paris.

Olawale, L. S. (20I4). International financial reporting standard adoption and banks performance in Nigeria. Retrieved from http://sstn.com/abstract $=2513212$.

Olawale, S. A. \& Olaniyi K. L. (2015). Equity share price determinants: a survey of literature. Arabian Journal of Business and Management Review, 5(3), 38-54.

Olugbenga, A. A., \&Atanda, O. A. (2014). The relationship between financial accounting information and market values of quoted firms in Nigeria. Global Journal of Contemporary Research in Accounting, Auditing and Business Ethics (GJCRA),I (I), 22 -39.

Omoye, A. S. \& Eriki, P. O. (20I4). Corporate governance determinants of earnings management: Evidence from Nigerian quoted companies. Mediterranean Journal of Social Sciences, 5 (23) $553-564$.

Oshodin, E., \&Mgbame, C. O. (2014). The comparative study of value relevance of financial information in the Nigeria banking and petroleum sectors. Journal of Business Studies Quarterly,6(I), 42-54. 
Oyerinde, D. T. (2009).Value relevance of accounting information in emerging stock market in Nigeria. Proceedings of the IOth annual international conference. International Academy of African Business and Development (IAABD), Uganda.

Oyerinde, D. T. (20II). Value- relevance of accounting information in the Nigerian Stock Market. The Department Of Accounting, Covenant University, Ota, Nigeria.

Oyerinde, D. T. (20II).Value- relevance of accounting information in the Nigerian stock market. Ph.D Thesis, Covenant University, Ota, Nigeria.

Oyerinde, D. T. (2012).Value relevance of accounting information in the Nigerian Stock Market. A PhD thesis in the department of accounting, submitted to the School of Postgraduate Studies, Covenant University, Ota, Nigeria.

Ozlen, S. (20I4). The effect of company fundamentals on stock values. European Researcher, (7I), 3-2.

Pandey, I. M. (2005). Financial management. IOth ed.. New Delhi: Vikas Publishing House PVT Ltd.

Perera, R.A.A.S. \& Thrikawala, S.S. (2010). An Empirical Study of the Relevance of Accounting Information on Investor's Decisions. In: Proceedings of the Ist International Conference on Business and Information, University of Kelaniya.

Piot ,C. \& Janin ,R. (2007) . External auditors, audit committees, and earnings management in France. European Accounting Review, I6(2), 429.

Quintus, V. (2007). The conceptual framework, accounting principles and what we believe is true. Accountancy SA; Accounting \& Tax Periodicals, 30-33.

Shehzad, K., \& Ismail, A. (20I4). Value relevance of Accounting Information and its Impact on Stock Prices: Case Study of Listed Banks at Karachi Stock Exchange. Journal of Economic Info, 3(I), 40-48, 2014

Shleifer, A. \& Vishny, R.W. (1997). A survey of corporate governance. The Joumal Of Finance, LII, (2), 737-783.

Stulz, R.M. (2005). The Limits of Financial Globalization. NBER Working Papers IIO70, National Bureau of Economic Research, Inc.

Tsalavoutas, I., Andre, P., Evans, L. (2012). The transition of international financial reporting standards and the value relevance of financial statements in Greece. The BritishAccounting Review, 44, 262-277.

Uthman, A. B., \& Abdul-Baki, Z. (20I4). The value relevance of accounting information in Nigeria. Journal of Accounting and Management (JAM), 4(I), 43-58.

Uwuigbe,U., Olusegun,O.,\& Godswill,A. (2012). An Assessment of the Determinants of Share Price in Nigeria. ACTA Universities Danubius; 8 (6), 56-78.

Vijitha, P., \& Nimalathasan, B. (20I4). Value relevance of accounting information and share price: A study of listed manufacturing companies in Sri Lanka. Merit Research Journal of Business and Management 2(I) 00I-006.

Wang, J., Fu, G., \& Luo, C. (20I3). Accounting information and stock price reaction of listed companies-empirical evidence from 60 listed companies in Shanghai Stock Exchange. Journal of Business \& Management, 2(2), II-2I.

Watts, R.L. \& Zimmerman, J.L. (1986). Positive accounting theory. Englewood Cliffs, N.J.: Prentice- Hall

\section{Copyrights}

Copyright for this article is retained by the author(s), with first publication rights granted to the journal. This is an open-access article distributed under the terms and conditions of the Creative Commons Attribution license (http://creativecommons.org/licenses/by/4.0/). 